\title{
The Growing Importance of Local Pumpkin Seed Oil Production in Slovenia
}

\author{
Maja Godina Golija \\ Institute of Slovenian Ethnology, \\ ZRC SAZU
}

\begin{abstract}
Food represents a significant segment of human culture. It is not only a component of the material world and a means to satisfy basic biological needs, but also plays an important role in the economic and social life of the individual and community. Until the middle of the $20^{\text {th }}$ century, the food culture of the Slovene population strongly depended on regional origin. Pumpkin seed oil has a special dietary role and a long tradition among the inhabitants of NorthEast Slovenia and the cultivation of oil seed pumpkins and production of pumpkin seed oil in the region was already mentioned in $18^{\text {th }}$ century. Slovene pumpkin seed oil is of high-quality and is processed according to the traditional procedure. Since 2005, Styrian-Prekmurje pumpkin seed oil has been protected in the European Union with the Geographical Indication-PGI.

Nowadays, the pumpkin seed oil is also becoming an important expression of regional affiliation and a notable factor of economic development in Prekmurje, Porabje and Štajerska, especially significant for tourism, catering and the production of traditional rural products.
\end{abstract}

Keywords: pumpkin seed oil, food culture, Slovenia, economic development, tourism, heritage

\section{INTRODUCTION}

The production, preparation, and consumption of food are among the most basic of human activities and are associated with those rare cultural goods that are produced on a daily basis (WIEGELMANN 2006:13). In past centuries, when the majority of the European as well as the Slovene population depended on their own food production, most of their economic activities were connected with it. As late as the 1940s, the renowned Slovene ethnologist Rajko Ložar wrote that most of the activities on Slovene farms were related to the provision of adequate quantities of food. Agricultural activities for the provision of other basic goods and the sale of farm products were therefore of lesser importance (LOŽAR 1944:192).

The food consumed by the majority of the Slovene population was distinctly seasonal and regionally diverse by the end of the $1950 \mathrm{~s}$, when the purchasing power and the standard of living started to gradually increase (Godina GoliJA 2006:51). A part of the 
rural population then moved to urban centres and obtained employment in industrial plants, thereby increasing the percentage of daily commuters travelling from rural areas to jobs they obtained in nearby industrial centres. These changes had a marked impact on the lifestyle of Slovene families, influencing their daily rhythm and also their food culture. Families became gradually dependent on store-bought food. Their daily meals were undergoing significant changes, and regional differences in the food culture of the Slovene population began to diminish (Godina GoliJa 2008:97). Due to better infrastructure and means of communication as well as migration, certain regional specialties in the local food culture gradually filtered into the cuisine of other Slovene regions or started to become culinary attractions served in restaurants and other catering establishments.

One such regional specialty is pumpkin seed oil. Due to its dark colour and very distinctive, unique taste, it had been despised for several centuries as low-quality oil by the majority of Slovenes, who preferred light cooking oils. It was used mainly in the eastern part of Slovenia, primarily in Prekmurje, Štajersko, and Porabje. During the last four decades, however, pumpkin seed oil was gradually included in the cuisine of other Slovene regions, which was largely because of its reputation for being, much like olive oil, quite beneficial to health, infusing certain dishes with a highly distinct flavour that could not be replaced by any other oil.

\section{METHODOLOGICAL STARTING POINTS OF THE RESEARCH}

Even though older ethnological sources and literature mention a great variety of oils that were once used in Slovenia (LožAR 1944:204; NovAK 1960:174), such as poppy-seed, linseed, rapeseed, olive and pumpkin seed oil, the skill of oil-making and the types of oil consumed by the Slovene population have not yet been adequately researched. The only exceptions were a handful of studies, published in the last two decades, on the production and use of olive oil in Istria and Primorsko, written by Zora Žagar (ŽAGAR 1985). These were mainly a result of the increased interest in the production and sale of olive oil on the market, the needs of tourism, and the promotion of local cuisine and cultural heritage. Ethnologists from this region have also participated in the renovation and revitalization of an old olive mill, the torklja, in Sv. Peter in Istria, where a number of other events take place in addition to the demonstration of olive oil production. In the promotion of local cuisine and cultural heritage, other types of oil are represented to a much smaller extent, and important objects, a testimony to their production and great economic importance for the local community, are unfortunately in a state of increasing decay. Only rare individuals who work to preserve this part of cultural heritage are aware of their importance for the cultural heritage and culinary tradition of a given region (Косвек 2008).

In view of this, I have decided to study and present a still thriving element of intangible heritage typical of the North-Eastern part of Slovenia, namely the heritage associated with the production and use of pumpkin seed oil. My research was carried on within the framework of the Living Heritage research project conducted by the Institute of Slovenian Ethnology of the Research Centre of the Slovene Academy of Sciences and Arts (ISN ZRC SAZU) in the period between 2009-2011. The primary goal of the researchers working on this project was to identify and investigate a unit of the intangible cultural heritage of Slovenia in accordance with the UNESCO Convention for 


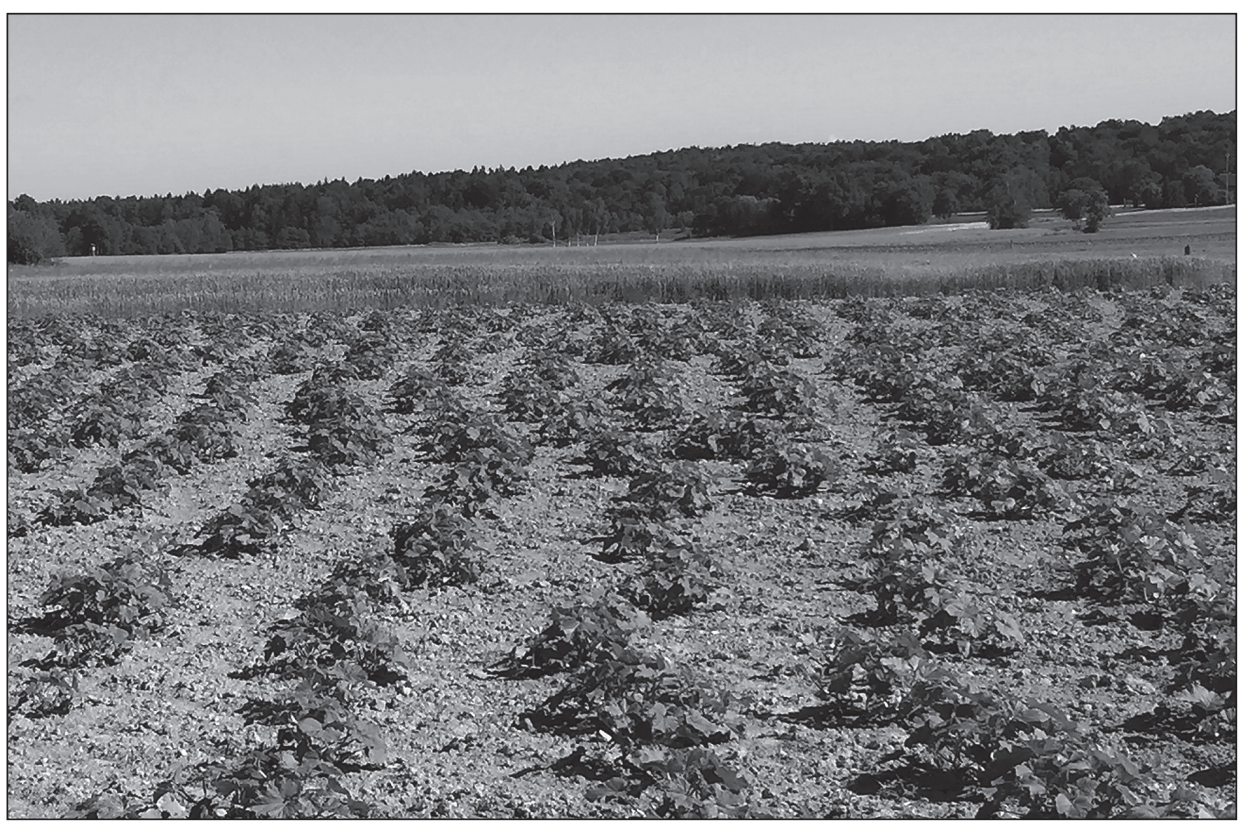

Figure 1. A field with pumpkins. Pomurje, Slovenia, 2017. (Photo by Maja Godina Golija)

the Safeguarding of the Intangible Cultural Heritage, ratified by the Slovene Parliament in 2008 (KRIŽNAR 2010:10). In agreement with this convention, food i.e. the preparation of dishes and food products, their consumption, and their inclusion in rituals, customs, and social events is one of the areas of the intangible cultural heritage that contains a high level of human creativity and knowledge. As part of intangible cultural heritage, food culture is namely of considerable importance for the lives of family members and the community; for the consolidation of their ethnic, local, and regional identities and for the preservation of cultural diversity (GoDINA GoliJA 2012:95). Based on these definitions, it has been ascertained that, in addition to some other elements of the Slovene food culture, pumpkin seed oil corresponds perfectly to the following desired characteristics of intangible cultural heritage: a high level of technical knowledge and skill; specific formulas, use in regional cuisine, a connection with certain beliefs and knowledge of folk customs, but also an increasing importance of food culture heritage in emphasizing ethnic and regional identity and in tourist development.

Pumpkin seed oil is particularly important in various forms of sustainable tourism, which is based on local tradition, geographical features, and ethnological heritage. In accordance with the related findings of ethnologists in other European countries (KöSTLIN 2010; Tellström 2006; TsChOFFEN 2010), it is possible to say that in Slovenia interest in local agricultural products, foodstuffs and recipes for the preparation of traditional dishes is on the increase. This is mainly due to growing interest in food of higher quality that is produced locally, in healthy diet, and in a balanced lifestyle in accordance with local possibilities and geographical features.

My ethnological research on pumpkin seed oil included fieldwork, which started in the region of Stajersko in 2010. In addition to a modern oil factory, the village of Fram 
has one of the oldest pumpkin seed oil mills. The plant, which dates from 1750, is now abandoned and in increasing decay. I have conducted narrative interviews with the heirs of its original owners as well as with the current pumpkin seed oil producers in Štajersko. In 2010, 2011, 2013, and 2017, I studied the production of pumpkin seed oil in the area of Pomurje. Semi-guided interviews were conducted in Petanjci, Tišina, Sv. Jurij ob Ščavnici, and Krog, where I talked with pumpkin seed oil producers, oil mill owners, and farmers who grow oilseed pumpkins for their own needs. By applying the method of participant observation, I monitored different phases of the preparation and production of pumpkin seed oil. In 2013, 2014 and 2015, I also conducted fieldwork among Slovenes in Hungary. In the villages of Orfalu/Andovci, Alsószölnök/Dolnji Senik, Felsőszölnök/ Gornji Senik, Szakonyfalu/Sakalovci, Apátistvánfalva/Števanovci, and in the town of Szentgotthárd/Monošter, I conducted semi-guided interviews on the traditional food culture of Slovenes living in this area and on the production and use of pumpkin seed oil in local Porabje cuisine. I amassed an extensive amount of photographic material depicting the production of pumpkins and the hulling of their seeds, the production of pumpkin seed oil in oil mills, its sale in oil plants, shops, and fairs; and its promotion. In addition to field research, I studied relevant archival data and newspaper articles, pictorial sources, web data, and ethnological as well as historical literature.

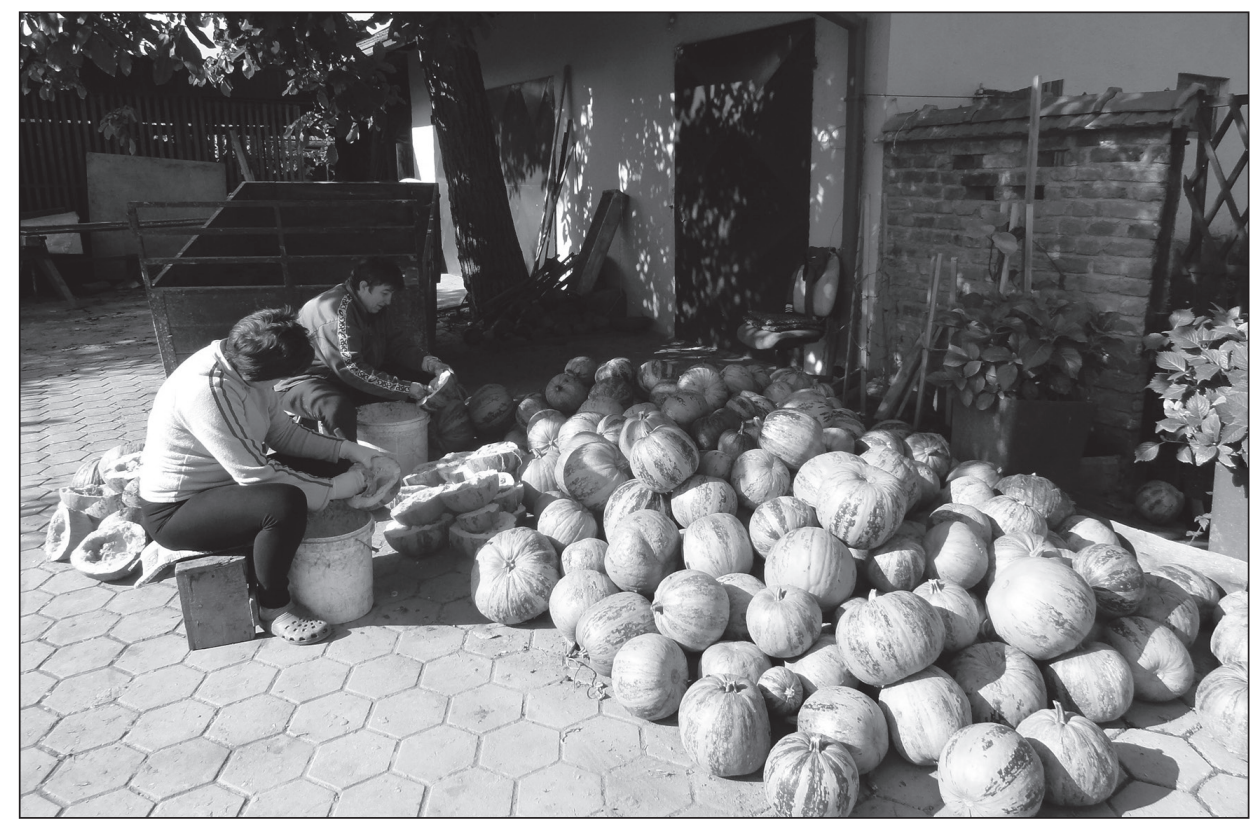

Figure 2. Peeling pumpkin seeds. Krog, Slovenia, 2013. (Photo by Maja Godina Golija)

In the course of my research on pumpkin seed oil as an important component of the food culture of the population of Stajersko, Pomurje and Porabje, I proceeded from current theoretical starting-points claiming that pumpkin seed oil is more than just food that satisfies people's basic needs, being an element of material culture with significant ethnological relevance. This provides an insight into the economic, social, and cultural 
importance of pumpkin seed oil and shows its significant role in identifying and preserving national and regional identity, and in the perception of health and sustainable development (BUCHLI 2002:17).

\section{A GLIMPSE INTO THE PAST}

The growing of pumpkins and their use in the local diet spread throughout Prekmurje, Porabje and Stajersko in the $17^{\text {th }}$ century, along with the cultivation of maize. Pumpkins were especially popular because they could be planted in the interim between two other crops. According to sources, the extraction of pumpkin seed oil was initially a task associated with farming, and it was not until the mid- $18^{\text {th }}$ century that archival sources mention the first oil mills that produced pumpkin seed oil for sale. The aforementioned oil mill in Fram was cited as the oldest mill for the production of pumpkin seed oil in Slovenia. In the $19^{\text {th }}$ century, Fram already had three oil mills (ŽIžEK 1978). The famed pumpkin seed oil mill in Slovenska Bistrica was established in 1904. ${ }^{1}$ Since oil production in these factories exceeded domestic needs, pumpkin seed oil was also exported to more distant Austrian provinces.

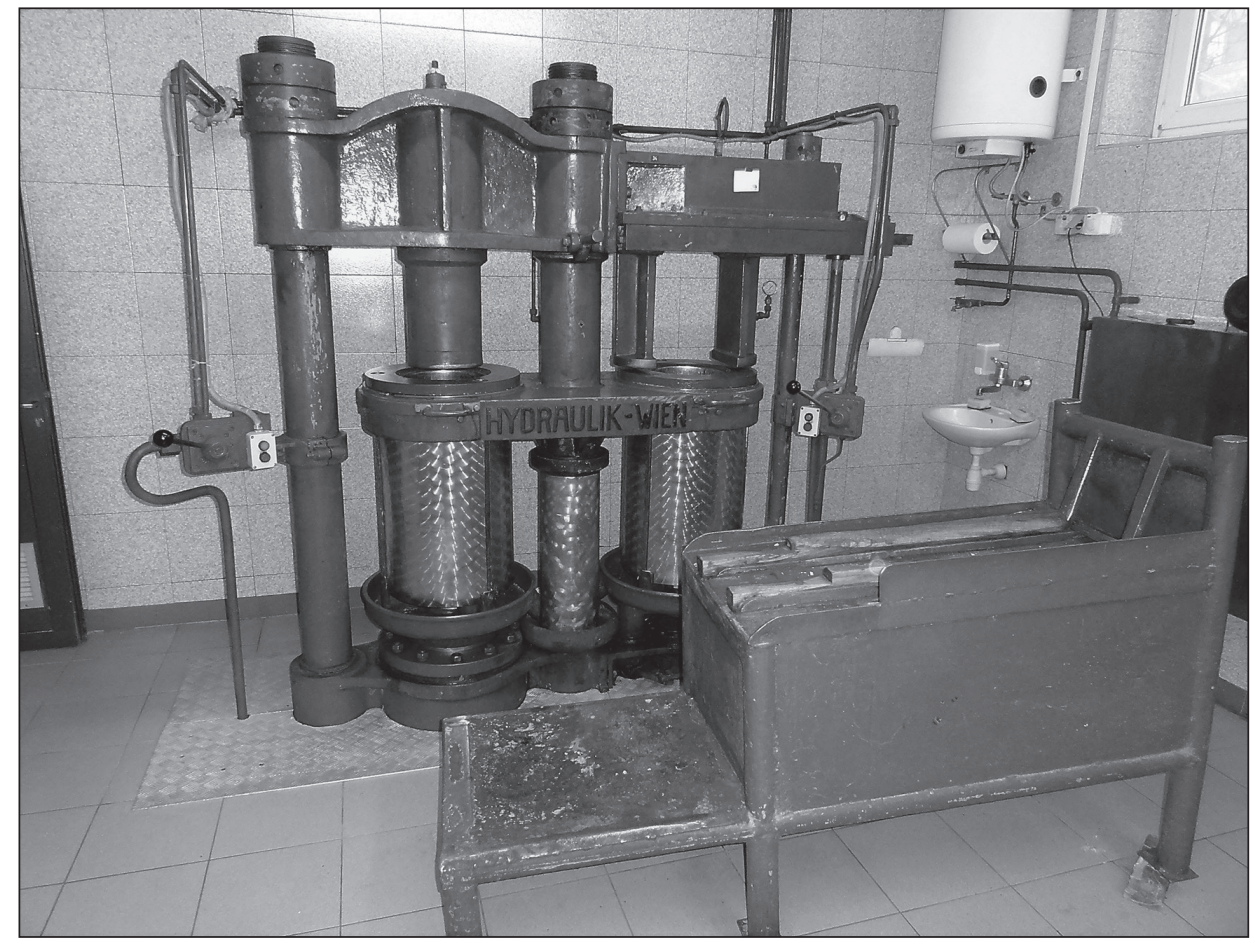

Figure 3. Old hydraulic press for producing pumpkin seed oil. Fram, Slovenia, 2010. (Photo by Maja Godina Golija)

${ }^{1}$ http://www.gea.si/en/about-us/history (accessed June 5, 2017.) 
In the past three centuries, the production of pumpkin seed oil was therefore largely a domestic agricultural activity that gradually developed into a craft and, subsequently, the broader, specialized production of oil (BOGATAJ 1989:85). By the late $19^{\text {th }}$ and early $20^{\text {th }}$ century, the economic importance of the production of pumpkin seed oil had increased. As a result, the share of arable land in north-eastern Slovenia for the production of pumpkin seeds for oil increased as well. In 1875 , as much as $0.82 \%$ of the arable land in Štajersko and in a part of Prekmurje was cultivated with pumpkins. By comparison, during the same year and in the same areas, $0.30 \%$ of arable land was planted with rape, $3.17 \%$ with legumes, and $8.21 \%$ with potatoes. Most of the arable land in these two regions, however, was sewn with cereals: $16.79 \%$ with wheat and $16.61 \%$ with rye (BLAZNIK 1970:265).

Most of the pumpkin-oil mills still operating in Prekmurje and Štajersko were established in the early $20^{\text {th }}$ century. In addition to their regular activities, many local millers also started to produce pumpkin seed oil. Such smaller oil mills have been organized as family businesses, and the third or fourth generation of family members now continue this work. One such example is the famed Kocbek oil plant in Stara Gora near Sv. Jurij pri Ščavnici, which has been in operation since 1929. G. K., its current owner, told me in 2010 that oil production was initially launched by his grandfather, who was a miller by profession. He then gradually expanded his milling business to include the production of pumpkin seed oil and concentrated solely on its production following the Second World War.

Due to the flourishing production of pumpkin seed oil in Štajersko and Prekmurje, there was already an increasing shortage of domestic pumpkin seeds - the bučnice in the 1920s and 1930s. Additional seeds were imported from other parts of what was then the Yugoslav monarchy, especially from Croatia and Serbia. Pumpkin seed oil from Stajersko and Prekmurje, renowned for its high quality, was also sold to Kranjsko and neighbouring Austria, where it was used quite frequently. ${ }^{2}$ Prior to the Second World War, the famed food retailer Julius Meinl from Vienna, Austria annually purchased three to four wagons of pumpkin seed oil from Fram for his commercial network. My informant, K. P., told me that pumpkin seed oil from Štajersko was especially popular with the merchants from the Austrian cities Graz and Leoben. The oil was dispatched there by the so-called Southern Railway from the railroad station in Fram.

During the early 1980 s, oil producers began to use a special, locally grown variety of pumpkins, the so-called buča golica (cucurbita pepo var. Styriaca), which has swiftly replaced older varieties. Whereas a great deal of time was once required for the preparation of pumpkin seeds, the new pumpkin variety makes it possible to significantly shorten this process because its seeds are merely dried, but not hulled.

The majority of Slovene pumpkin seed oil mills operate in Štajersko and Prekmurje, where Slovenes from the region of Porabje (in Hungary) take their pumpkins for processing. Most of the pumpkin seed oil is now sold on the Slovene market, but it is also exported to Austria, England, Ireland, and even the Baltic states. Pumpkin seed oil from Slovenia, called Štajersko-Prekmursko Pumpkin seed oil, has been protected by the European Union with a designation of Protected Geographical Indication since 2004. ${ }^{3}$

\footnotetext{
${ }^{2}$ http://www.oljarnafram.si/en/production-of-edible-oils/ (accessed May 31, 2017.)

${ }^{3} \mathrm{http} / / / w w w . s l o m e d i a . i t / s t a j e r s k o-p r e k m u r s k o-b u c n o-o l j e-z e-15$-slovenski-proizvod-zasciten-v-eu/2 (accessed May 23, 2017.)
} 


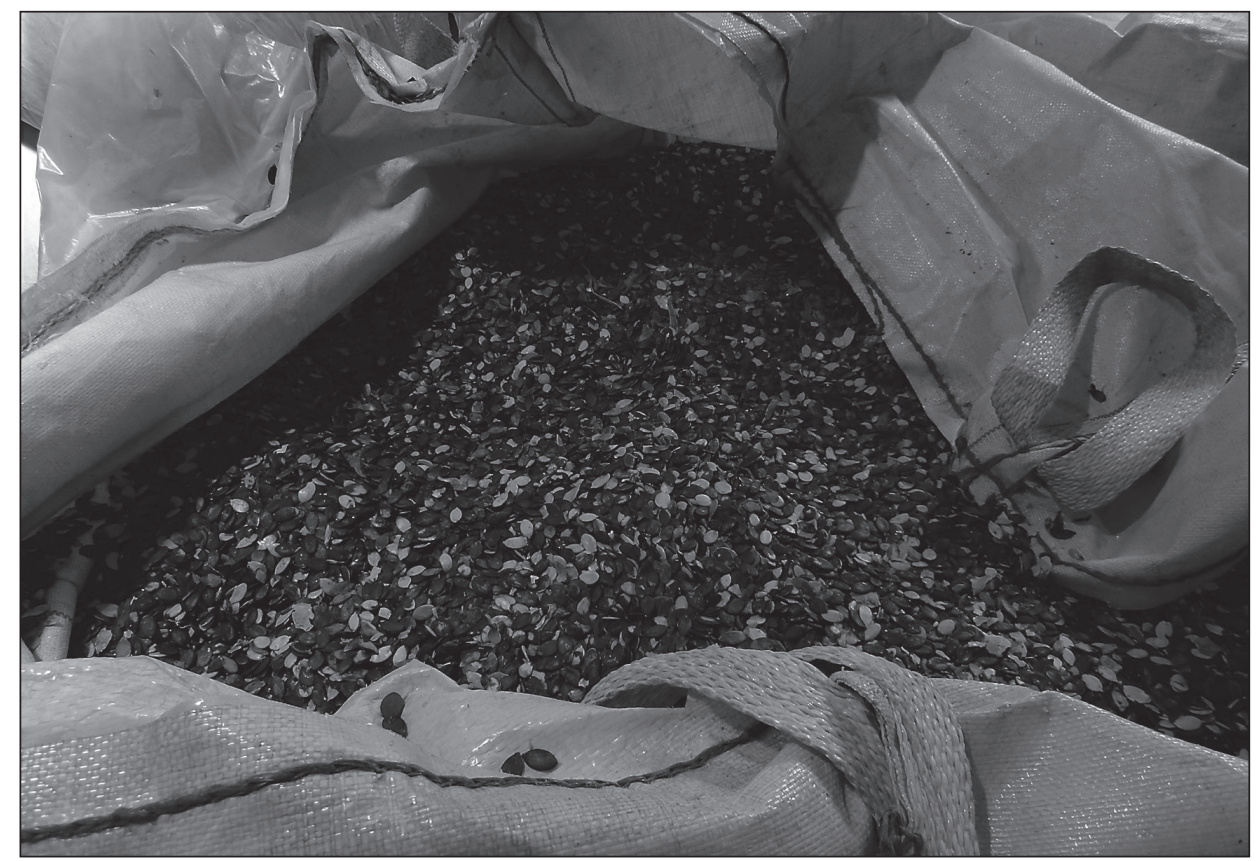

Figure 4. Dried pumpkin seed. Fram, Slovenia, 2010. (Photo by Maja Godina Golija)

\section{METHODS OF EXTRACTING PUMPKIN SEED OIL AND THE TRADITIONAL FORMULA}

Pumpkins, which were used for the production of oil as well as feed for poultry and pigs, were planted throughout Slovenia, but not in the quantities found in Štajersko, Prekmurje, and Porabje. They were either planted among corn or as the main crop in the field. Until the 1980s, the use of dried and shelled pumpkin seeds (bučnice) of lighter colour was still widespread. Since these had to be extracted from the centre of the pumpkin by hand, which was a time-consuming task, they were replaced by the so-called golice pumpkins. Their introduction greatly simplified the oil-making process. B.G., an informant from Fram, thus described the now obsolete process:

\footnotetext{
“Since 1982, we've been using the seeds produced by the golice pumpkins. In the past, however, we had to extract the white seeds manually, wash and dry them in order to separate the seed from the hull more easily, and transport them to a machine that sorted them in four sizes. The seeds were then crushed under a rough-hewn stone. Another machine separated the hulls from the seeds and then transported the hulled and cleaned seeds to the rolling mill for grinding."
}

Most of my informants stated that the old, manual process produced a much tastier oil that also had a better colour. Since the hulls had been completely removed, the oil was a shade lighter and had a fuller taste whereas now the entire seed is ground, thus producing a different taste and colour. 
In the subsequent phase of production, ground seeds are mixed with an optional combination of water and salt to produce a creamy substance, which is then blended in a mixer to start emitting oil. The resulting mass is poured into a pan and roasted at 96 degrees Celsius for approximately forty minutes. The mass has to be constantly mixed to prevent it from burning. Roasting pans are installed with special knives which ensure that, the mixture does not stick to the bottom, despite high temperatures. When the roasting process is completed, the mixture is compressed under high pressure (about 350 bar). Extracted oil is then poured into tanks, where it remains for approximately two weeks to clear and produce sediment. The oil is then pumped into clean tanks and left there to purify for up to three weeks. The completely purified oil is then bottled and stored in a cool and dark place, where its shelf life is one year.

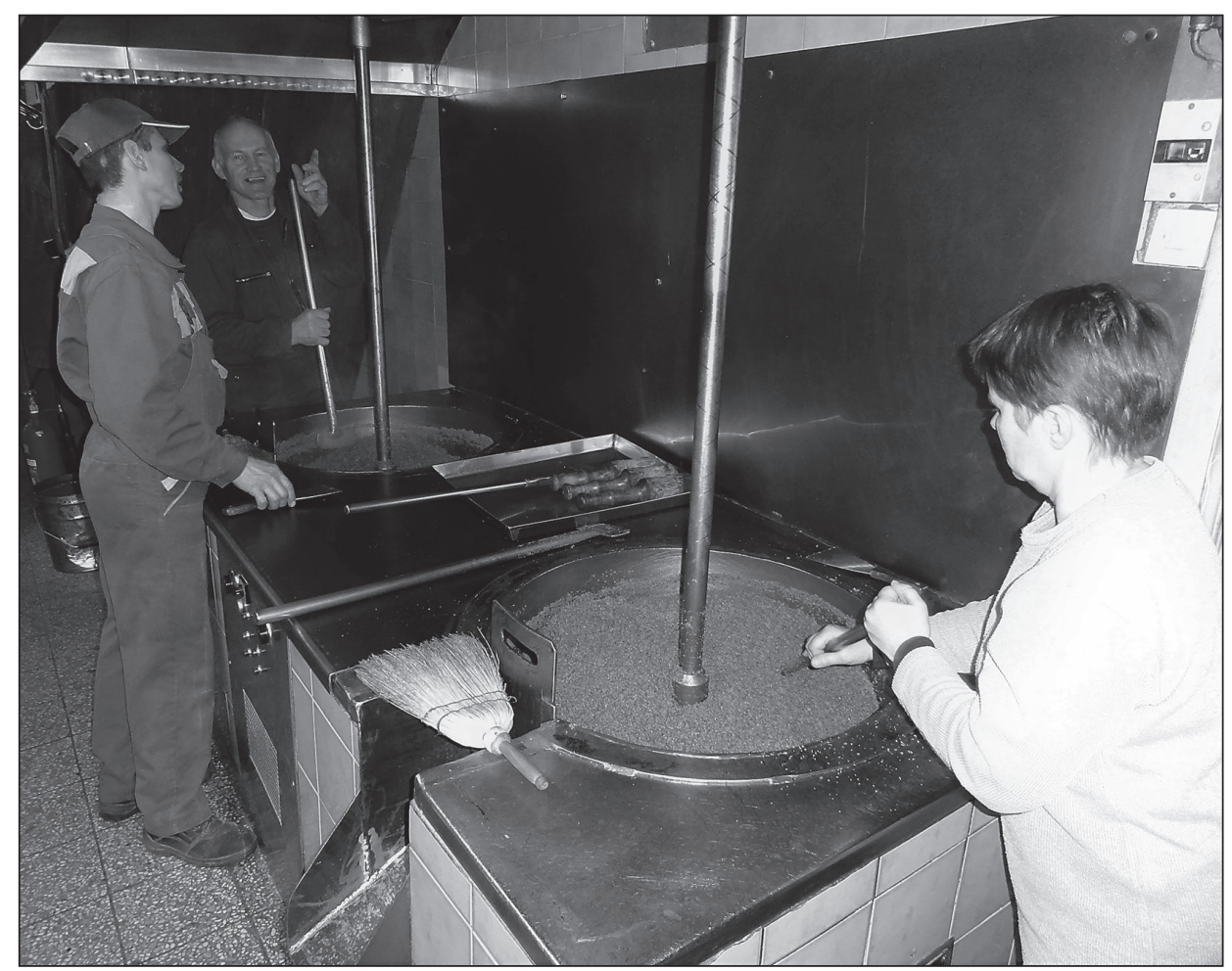

Figure 5. Roasting pumpkin seeds. Stara Gora pri Juriju ob Ščavnici, Slovenia, 2011. (Photo by Maja Godina Golija)

Hydraulic presses were used in many locations prior to the Second World War. Pumpkin seeds were also roasted at a much higher temperature, generally at 120 degrees or more, which the current legislature prohibited in order to protect human health.

The oily remains of the pressed and roasted mass are called the prga. Pressed into flat cakes and extremely nourishing, they were once used by farmers to feed cows and pigs, but also in fisheries. Before the Second World War, these were even exported to Czechoslovakia, Italy, Germany, and Hungary. 


\section{PUMPKIN SEED OIL IN TRADITIONAL SLOVENE CUISINE}

Pumpkin seed oil has been the most widespread and commonly used oil for seasoning dishes and salads in Northeast Slovenia over the last two centuries. White vegetable oil and olive oil were very expensive for most people as they were imported from distant Slovene and foreign regions. They were almost inaccessible to the majority of the population and were therefore used very rarely or not at all.

Pumpkin seed oil is mentioned by Velko Novak in his detailed study on the food culture of the rural population in the Prekmurje region entitled Ljudska prehrana $v$ Prekmurju (Novak 1947:93). The oil is cited as being an important ingredient of the regional cuisine. Novak claims it was used for seasoning salads, potatoes, head cheese (or brawn) and beans.

Prior to major changes in the traditional cuisine of North-East Slovenia in the 1960s, pumpkin seed oil played a special role, especially in preparing meals during the spring and summer, when gardens and fields were full of lettuce and vegetables. These meals were prepared with pumpkin seed oil, vinegar and other condiments, resulting in a single meal, usually at lunch time. In the spring, locals picked dandelion and lamb's lettuce, seasoned it with pumpkin seed oil and added potatoes to make a rich single meal to be enjoyed with bread. In summer, they used pumpkin seed oil on cucumbers, boiled green beans and different types of lettuce, in autumn and winter, when fresh vegetables and lettuce were scarce, pumpkin seed oil was used to prepare dishes with beans, boiled potatoes, sauerkraut and black radishes. Pumpkin seed oil was also added to cooked meat, young cheese and cottage cheese (KoZAR - MuKIČ 2014:122; NovAK 1947:17).

In Porabje, the Hungarian region populated by Slovenians, pumpkin seed oil has played a significant role in past centuries. Therefore, Slovene farmers from the area strove to cultivate enough pumpkins to produce sufficient quantities of oil for their personal use. I. D., from the village of Števanovci, said: "Until the end of the 60s, we had an oil mill in Gornji Senik, where we would take pumpkin seeds to be pressed into oil. We dried them and shelled them at home in the winters from around $6^{\text {th }}$ of January to $19^{\text {th }}$ of March."

In the region of Porabje, as in Slovenia, pumpkin seed oil was used for seasoning salads, sauerkraut and beans (ČABAI 2000; KoZAR - MUKIČ 2014). Beans with pumpkin seed oil was considered the food of beggars for a long time in this region because of its ability to satiate quickly. A combination of Sauerkraut and beans seasoned with pumpkin seed oil was even more popular among Slovenians in the region. They call it straušanca and they still prepare it on special occasions as their typical dish (KozAR - Mukič 2014:122). They also prepare it for the annual "Porabski dnevi" event held at the Lipa Hotel in Monošter.

According to several sources from the region, pumpkin seed oil is the one ingredient that separates the cuisine of the Slovenians of Porabje from Hungarian cuisine, which does not incorporate pumpkin seed oil in traditional dishes. Slovenians in Hungary see pumpkin seed oil as an important indicator of their national identity, which, along with other cultural elements, separates their community from the mainstream Hungarian one. In the course of my fieldwork in 2014, a Slovene source from the Porabje region told me: "Pumpkin seed oil is used in kitchens all the way to Monošter, and that is also where Slovenians live."

Today, as there are no pumpkin seed oil mills left in Porabje and the border is open and easily crossed, the local people take dried pumpkin seeds using their own vehicles to oil 
mills in Prekmurje, especially the ones in Križevci and Petišovci. There they can exchange their pumpkin seeds for pumpkin seed oil for their own personal use. The ones who do not have enough oil can also buy Slovene pumpkin seed oil in supermarkets in Prekmurje.

In North-East Slovenia, pumpkin seed oil has stayed at the forefront of all types of oil used for cooking in Styria, Prekmurje and Porabje. It is used in the preparation of traditional dishes and salads as well as new culinary masterpieces (BOGATAJ 2000:222). Its special flavour and colour are what separates it from other types of oil, and pumpkin seed oil is becoming more and more popular in the gastronomy of other Slovene regions as well as abroad.

\section{NEW PRACTICES IN PUMPKIN SEED OIL EXTRACTION AND USAGE}

Having played an important role in the everyday and festive diet of the Slovene population in Styria and the regions of Pomurje and Porabje for two and a half centuries, pumpkin seed oil has also spurred some new practices over the last two decades with regards to its production in oil mills and its use in contemporary cuisine. These practices represent an incentive for the local economy. The introduction of golica, a new pumpkin sort, has drastically changed the traditional production of pumpkin seed oil as well as its typical colour, flavour and quality. A simpler and shorter way of preparing pumpkin seeds and pumpkin seed oil has encouraged the abolishment of what was once a common and widespread farming activity; scraping out pumpkin seeds, drying them and shelling them during winter evenings. Today, the preparation of pumpkin seeds from the golica pumpkin takes far less time and effort, and it does not require as much teamwork.

The procedure for roasting pumpkin seeds to extract oil has seen major changes in the last ten years in accordance with European and Slovene laws. The seeds are no longer roasted at temperatures above 100 degrees Celsius. Due to growing interest among European and domestic consumers in cold pressed vegetable oils, pumpkin seed oil producers have tried to find the recipe for extracting pumpkin seed oil via low temperature seed roasting i.e. cold pressed oil production. ${ }^{4}$ The Kocbek foil mill in Stara Gora, near Sveti Jurij ob Ščavnici, is at the forefront of these endeavours and new pumpkin seed oil production methods in Slovenia. Its owner, G. K., told us that the mill has developed a method for cold pressed pumpkin seed oil production based on years of experience and many attempts. This method involves pumpkin seed roasting at just 40 degrees Celsius, preserving a higher mineral, microelement and vitamin content in the pumpkin seed oil. Because of lower temperature seed roasting, the oil has a different, lighter colour and a subtler flavour. It is offered as a gastronomic specialty in the finest restaurants and shops in Slovenia and abroad (KocBeK 2008:6).

In addition to the new pumpkin seed oil production method, Slovene cuisine has over the last decade introduced several recipes that use pumpkin seed oil for food preparation in novel and previously unknown ways. In the past, the pumpkin seed oil was predominantly used for seasoning salads, legumes and root crop dishes, whereas today, chefs from North-East Slovenia have prepared recipes for new main dishes and

\footnotetext{
${ }^{4}$ https://www.domacedomace.si/blog/bucno-olje-razlika-med-toplo-in-hladno-stiskanim-bucnimoljem/ (accessed May 30, 2017.)
} 
desserts with pumpkin seed oil. These dishes are a welcome addition to the established culinary offering in this area and a contribution to a broader selection for visitors of the region. New pumpkin seed oil dishes worth mentioning are: fried trout in pumpkin seed oil sauce, pumpkin seed and pumpkin seed oil spread, pumpkin seed oil pasta, pumpkin cream soup with pumpkin seeds and pumpkin seed oil and bread with pumpkin seeds and pumpkin seed oil. Nowadays, it has become very popular to use pumpkin seed oil in desserts, which is something new in Slovene cuisine as pumpkin seed oil in the past had been used solely for salads and main dishes. Vanilla ice cream with pumpkin seed oil is also a very popular dessert these days, as are pumpkin seed oil rolls, cakes and cookies. At Christmas 2012, M. P., a chef and cooking instructor from Maribor, surprised everyone with a recipe for outstanding chocolate pralines with pumpkin seeds and pumpkin seed oil.

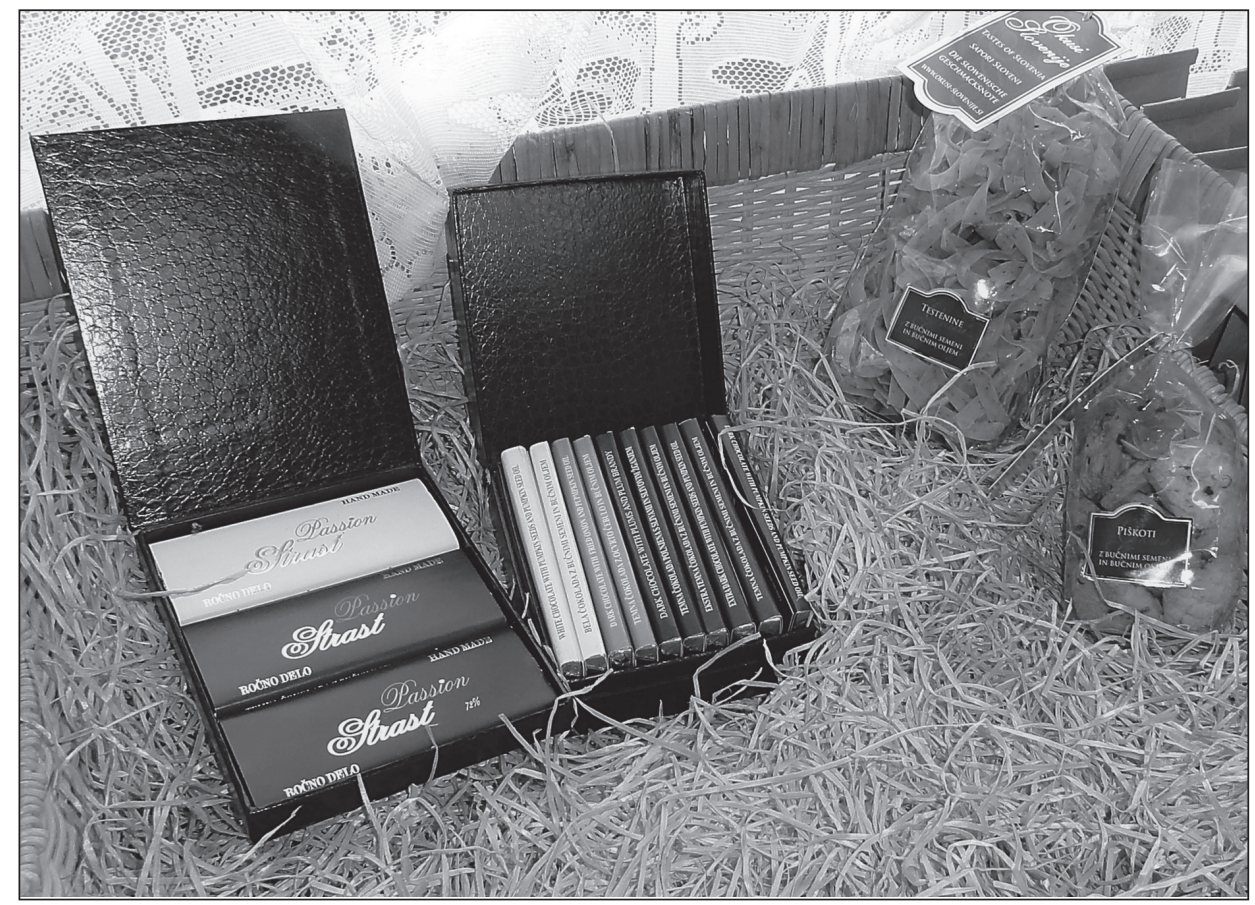

Figure 6. New products with pumpkin seed oil: chocolate, biscuits and pasta. Kocbek, Stara Gora pri Juriju ob Ščavnici, Slovenia, 2011. (Photo by Maja Godina Golija)

Along with restaurants and tourist centres that serve new pumpkin seed oil dishes in the Prekmurje region and in Styria, some of the oil mills selling pumpkin seed oil have also started to sell new products with this oil. The Kocbek oil mill has started making chocolate with pumpkin seeds and pumpkin seed oil and pasta as well as cookies with added pumpkin seed oil. Recently, people have also started to discover the healing effects of pumpkin seed oil, which has positively affected sales in Slovenia and abroad. We need to point out the positive effects of vitamin E and plant sterols, which inhibit ageing processes and which, as antioxidants, positively affect the cardiovascular system and 
inhibit cancerous growths, especially in the case of prostate cancer. ${ }^{5}$ Swedish ethnologist Tellsttröm discovered that modern consumers appreciate the authenticity of foods, the way they are connected to healthy natural ingredients and traditional production methods (TELlSTRÖm 2006:61), and this also applies to pumpkin seed oil and its use today. A balanced ratio between cultural heritage and innovation guarantees the market success of these authentic products.

\section{CONCLUSION}

Pumpkin seed oil is a relatively new ingredient in the Slovene diet, which has been for more than two centuries limited to only a small part of Slovene ethnic territory. Due to its specific taste and colour, it represented an ingredient which was in the past often despised and rejected by the majority of Slovenes. Despite the fact that pumpkin seed oil is merely an addition to dishes and salads and that it is only used in smaller quantities for the preparation of various dishes, in recent decades it has become increasingly important as a component of Slovenian food culture as well as an element of Slovenian intangible cultural heritage. In the present, an increasing interest in pumpkin seed oil closely related to the tourist industry can also be observed. In this regard, this simple rural product has become a significant factor of development in certain locals, thereby manifesting that it should not only be regarded as an important element of the intangible, but also of the material world on local and international levels. As a fragment of cultural heritage, pumpkin seed oil is also important for the local or ethnic identity of the Slovenian population. Ethnologists and anthropologists have already discussed that national dishes and typical regional food ingredients play a significant role for local communities, minority groups or for people living abroad (BUCHLI 2002; GodinA GoliJa 2014; Miller 2010; MlekuŽ 2015). As for pumpkin seed oil, it can also be detected that it has become important as a part of local and national identity, especially for the Slovenian population living in Hungary. In the Porabje region, Slovenian people understand pumpkin seed oil as an important sign of their national culture and tradition. It conveys messages about socialization, social inclusion and exclusion, the drawing of boundaries, and the overstepping of them (Douglas 1982).

In addition to this symbolic role the production and sale of pumpkin seed oil are also an important factor in the economy of Prekmurje, Štajerska and Porabje, where it has become an integral part of different festivals, for instance the Pumpkin Festival in Örség, as well as of tourist offers in health resorts in North-East Slovenia. Therefore, it is necessary to consider the changing processes of the significance of pumpkin seed oil for the local population and tourism. Its present importance for tourism, the catering industry and in the production of traditional local agrarian products and food, coincides with an increased interest in the autonomy and autarchy of European regions, a healthy lifestyle and the protection of nature (KösTLIN 2010:44).

It can be said that nowadays local rural products are the result of two distinct and contradictory processes: on the one hand, market demand for organic and traditional

\footnotetext{
${ }^{5}$ http://vizita.si/clanek/bilke/preizkusite-bucno-olje.html (accessed May 31, 2017.)
} 
food, and on the other, the rediscovery of local food products as a global phenomenon. Traditional food products, including pumpkin seed oil, converge in the general process of heritagisation, in which past elements are rediscovered and reinvented (GRASSENI 2011). All these practices play a significant role as means of local development and as bearers of collective territorial identities, which are also becoming increasingly important in Slovenian peripheral regions.

\section{REFERENCES CITED}

BAš, Angelos et al.

2004 Slovenski etnološki leksikon [Slovene Ethnological Lexicon]. Ljubljana: Mladinska knjiga.

BLAZnIK, Pavle et al.

1970 Gospodarska in družbena zgodovina Slovencev. Zgodovina agrarnih panog 1 [Economic and Social History of Slovenes. History of Agrarian Production 1]. Ljubljana: Državna založba Slovenije.

BogataJ, Janez

1989 Domače obrti na Slovenskem [Domestic Crafts in Slovenia]. Ljubljana: Državna založba Slovenije.

2000 Kuhinja Slovenije: mojstrovine nove kuharske umetnosti [Kitchen of Slovenia: the masterpieces of new cooking art]. Ljubljana: Rokus.

BUCHLI, Victor

2002 Introduction. In BucHLI, Victor (ed) The material culture reader, 1-23. Oxford

ČABAI, Hilda and New York: Berg.

2000 Slovenska kihinja ob Rabi / Szlovén konyha a Rába mentén. [Slovenian Cuisine Along the Rába River]. Monošter/Szentgotthárd: Zveza Slovencev na Madžarskem.

Godina Golisa, Maja

2006 Prehranski pokmovnik za mlade [Nutrition Glossary for Young People]. Maribor: Aristej.

2008 Oblikovanje sodobnega potrošnika. O. spremembah v preskrbi in pridelavi živil na Slovenskem [The Formation of the Modern Consumer. On the Changes in the Food Supply and Production in Slovenia]. Etnolog (69):95-111.

2012 Contemporary appropriations of culinary tradition in Slovenia. Traditiones 41(2):91-104.

2014 Potica in njene zgodbe. Slovenci v Srbiji in simbolni pomen hrane [Potica and Its Stories. Slovenes in Serbia and the Symbolic Significance of Food]. Dve domovini 39:55-66.

GRASSENI, Cristina

2011 Re-Inventing Food: Alpine Cheese in the Age of Global Heritage. Anthropology of Food. 8. http://aof.revues.org/6819 (accessed 26 May, 2017.)

KocBEK, Gorazd

2008 Štajersko-prekmursko bučno olje [Styrian-Prekmurje Pumpkin Seed Oil]. Ljubljana: Društvo za promocijo kakovostne hrane. 
KöstLIN, Konrad

2010 A new Ascension of Regional Food. In Lysaght, Patricia (ed) Food and Meals at Cultural Crossroads, 36-46. Oslo: Novus Press.

KozAR, Marija

2000 Etnološki slovar Slovencev na Madžarskem. A magyarországi szlovének néprajzi szótára [Dictionary of Slovene from Hungary]. Monošter Szombathely: Zveza Slovencev na Madžarskem, Savaria Múzeum.

Kozar-Mukic, Marija

2014 Prehrana v Pomurju in Porabju [Nutrition in Pomurje and Porabje]. In GodinA Golıu, Maja (ed) Prekmurje-podoba panonske pokrajine, 121-128. Založba: ZRC SAZU.

KRIŽNAR, Naško e tal.

2010 Živa kulturna dediščina se predstavi [A Live Cultural Heritage is Presented]. Ljubljana: Slovensko etnološko društvo.

LožAR, Rajko

1944 Ljudska hrana [Folk Diet]. In LožAR, Rajko (ed) Narodopisje Slovencev 1, 192-210. Ljubljana: Klas.

Miller, Daniel

2013 Stuff. Cambridge: Polity Press.

MLEKUŽ, Jernej

2015 Burek: a culinary metaphor. Budapest, New York: Central European University Press.

NovaK, Vilko

1947 Ljudska prehrana v Prekmurju [Folk Diet in Prekmurje]. Ljubljana: Slovenski knjižni zavod.

1960 Slovenska ljudska kultura [Slovene Folk Culture]. Ljubljana: DZS.

TELLSTRÖM, Richard

2006 The Construction of Food and Meal Culture for Political and Commercial Ends: EU-Summits, Rural Businesses and World Exhibitions. Örebro: Universitetsbiblioteket.

TsCHOFFEN, Bernhard

2010 Things, Senses, Practices: Experiencing Cultural Crossroads Through Hospitality and the Culinary System. In Lysaght, Patricia (ed) Food and Meals at Cultural Crossroads, 112-124. Oslo: Novus Press.

WIEGELMANN, Günter

2006 Alltags- und Festspeisen in Mitteleuropa. Innovationen, Strukturen und Regionen vom späten Mittelalter bis zum 20. Jahrhundert. Münster: Waxmann.

ŽAGAR, Zora

1985 Tonina hiša: etnološka zbirka v Ravnu [Tona’s House: Ethnological Collection ŽIŽEK, Albin in Ravne]. Piran: Pomorski muzej Sergej Mašera.

1978 Zapis o oljarni v Framu [A Record of the Oil Mill in Fram], a typescript. Maribor: Pokrajinski muzej. 


\section{ONLINE SOURCES}

http://www.slomedia.it/stajersko-prekmursko-bucno-olje-ze-15-slovenski-proizvodzasciten-v-eu/2 (accessed May 23, 2017.)

https://www.domacedomace.si/blog/bucno-olje-razlika-med-toplo-in-hladno-stiskanimbucnim-oljem/ (accessed May 30, 2017.)

http://vizita.si/clanek/bilke/preizkusite-bucno-olje.html (accessed May 31, 2017.)

http://www.oljarnafram.si/en/production-of-edible-oils/ (accessed May 31, 2017.)

http://www.gea.si/en/about-us/history (accessed June 5, 2017.)

Maja Godina Golija, Ph.D., studied ethnology, social history and philosophy at University Ljubljana and Westfälische Wilhelms University Münster. Since 1996, she has been employed with the Section for Material Culture of the Institute of Slovene Ethnology, ZRC Slovenian Academy of Sciences and Arts, where she mainly researches food, economy, social and urban life in Slovenia. She has written five monographs and more than 70 scientific articles and papers, especially on food culture and urban life. She is associate professor of the Ethnology of the Slovenes at the Faculty of Arts at University Maribor. She was a member of the executive presidency of the International Commission for Research into European Food History in 2003-2008 and in 2009-2010. She is also a member of the Slovene Ethnological Society, SIEF (Societé Internationale d'Ethnologie et de Folklore), where she is the vice president of the working group Food Research. In 2002 and 2003 she was editor-in-chief of the anthology Traditiones, and has been a member of the international board of editors of the anthology Bealoideas (Folklore Society of Ireland) and Etnolog (Slovenian Ethnographic Museum). 
